\title{
LIMITATIONS ON THE POWER OF STATE LEGISLATURES OVER PRESIDENTIAL ELECTIONS
}

\author{
JAMES C. KIRBY, JR**
}

\begin{abstract}
"... [I]f ever the tranquillity of this nation is to be disturbed, and its [liberties] jeopardized, by a struggle for power... it will be upon this very subject of a choice of a President. This is the question that is eventually to test the goodness, and try the strength of the Constitution...."

I James Kent, Commentartes on American Law 255-56 (i826).
\end{abstract}

Chancellor Kent went on to predict that if we could successfully elect our Presidents for the next fifty years, our institutions would be recommended to the "esteem and admiration" of enlightened mankind. His ranking of presidential elections above slavery as a peril to the nation's future and his prediction that the success of our electoral institutions would bring esteem and admiration proved the learned Chancellor to be a poor prophet on both counts.

After 173 years of experience, there are still unanswered questions inherent in the United States Constitution's simple directive that ". . . Each State shall appoint, in such manner as the Legislature thereof may direct, a Number of Electors ... ." In I8go, this language caused the Supreme Court to volunteer the dictum that state power over presidential elections is "unaffected by anything in the Constitution and laws of the United States ...." Two years later, in McPherson v. Blacker, the Court sustained an act of the Michigan legislature dividing the state into singleelector districts for election of presidential electors. In holding that the fourteenth amendment created no right of popular election of presidential electors and did not freeze the practice of electing them as a unit on a state-wide basis, the Court characterized state legislatures' power as "plenary." The right of any legislature to resume appointment of electors itself was expressly confirmed and the Court even suggested that the absolute power of any legislature could not be abdicated by statute or limited by state constitution.

Despite the broad sweep of these dicta, the power of state legislatures is not absolute. It is limited by certain provisions of the United States Constitution and by laws passed by Congress within its constitutional powers. State constitutions and the nature of the office of elector itself may also be limitations.

* B.A. I950, Vanderbilt University; LL.B., LL.M. 1954, New York University. Chief Counsel, Senate Judiciary Subcommittee on Constitutional Amendments, Washington, D.C. The author gratefully acknowledges the research assistance of Mr. Terry Lenzner of New York, N.Y., second-year law student at Harvard University.

${ }^{2}$ U.S. CoNsT., art. II, $\$ 4$.

${ }^{2}$ In re Green, 134 U.S. 377,380 ( $\left.x 890\right)$.

${ }^{3}{ }_{4} 6$ U.S. I (1892). 


\section{Federal Consttrutional Limitattons}

Since the various state legislatures have all now directed that presidential electors be appointed by popular election, the fourteenth, fifteenth and nineteenth amendments to the United States Constitution are limitations upon the prescription and administration of voting qualifications.

\section{A. Privileges and Immunities Clause of the Fourteenth Amendment ${ }^{4}$}

This provision is no impediment because voting in federal elections is not a privilege of citizenship of the United States. Thus, a Maryland law requiring that new residents of the state register and wait one year before voting was held not to violate any right under the Federal Constitution. ${ }^{5}$ Before women's suffrage, a state could limit voting to members of the male sex. ${ }^{b}$ Nor does the clause prevent a state from requiring payment of a poll tax as a prerequisite for voting ${ }^{7}$ or from using a nondiscriminatory literacy test as a voting qualification. ${ }^{8}$

\section{B. Equal Protection Clause of the Fourteenth Amendment ${ }^{9}$}

This is an effective limitation. Like all state laws, those regulating voting for presidential electors cannot impose discriminations which deny equal protection of the laws. Thus, the celebrated Texas "white primary" cases invalidated voter discrimination based on race, whether accomplished directly by state statute, ${ }^{10}$ or by a political party authorized by law to prescribe voting qualifications, ${ }^{11}$ or merely by a party rule restricting party membership where such membership is a prerequisite for voting in the primary. ${ }^{12}$ A literacy test scheme which on its face vests in an election official the arbitrary power to deny the right to vote has also been held to deny equal protection. ${ }^{13}$ Literacy test provisions which are valid and uniform on their face may nonetheless deny equal protection if administered in a discriminatory manner. ${ }^{14}$ It has been suggested that residence requirements which discriminated among citizens of the United States coming from different states would also be an unconstitutional classification. ${ }^{15}$

Suppose a state legislature again exercised its right to establish districts for the selection of presidential electors. The doctrine of Baker v. Carrio should preclude any invidious discrimination in the apportionment of population among districts.

\footnotetext{
"No state shall make or enforce any law which shall abridge the privileges or immunities of citizens of the United States. ..."

Sope v. Williams, r93 U.S. 621 (1904). 'Minor v. Happerset, 88 U.S. I62 (1874).

${ }^{7}$ Breedlove v. Suttles, 302 U.S. 277 (1937).

${ }^{8}$ Lassiter v. Northampton County Board of Elections, 360 U.S. 45 (1959).

D... nor shall any State... deny to any person within its jurisdiction the equal protection of the laws."

${ }^{10}$ Nixon v. Herndon, 273 U.S. 536 (1927). ${ }^{11}$ Nixon v. Condon, 286 U.S. 73 (1932).

${ }^{12}$ Smith v. Allwright, 321 U.S. 649 (I944).

${ }^{13}$ Davis v. Schnell, 8x F. Supp. 872 (S.D. Ala. I949), aff'd, 336 U.S. 933 (1949).

${ }^{14}$ Lassiter v. Northampton County Board of Elections, 360 U.S. 45 (1959) (dictum).

${ }^{16}$ Pope v. Williams, I93 U.S. 621, 634 (I904) (dictum).

${ }^{16}{ }_{369}$ U.S. I86 (1962).
} 


\section{Fifteenth Amendment ${ }^{17}$}

The present scope of the fourteenth amendment almost makes its unnecessary to look to the fifteenth as a limitation on state law. Although not an affirmative grant of the vote to members of the Negro race, ${ }^{18}$ this amendment expressly prevents discrimination in voting among persons because of race, color, or previous condition of servitude. The cases dealing with Oklahoma's attempt to retain its "grandfather clause" established that the fifteenth amendment is violated by laws which, although not discriminatory on their face, impose on Negroes onerous procedural requirements whose practical effect is to prevent their registration and to continue racial discrimination. ${ }^{19}$ Arbitrary or discriminatory administration of otherwise valid literacy tests conflicts with this amendment as well as the fourteenth. 20

\section{Nineteenth Amendment ${ }^{21}$}

Like the fifteenth amendment, this amendment is not an affirmative grant of the right to vote. It only removes from the states the power to abridge voting rights solely on account of sex. As a self-executing provision, its effect was to expunge the word "male" and the masculine pronoun from state laws and constitutions defining voting qualifications. ${ }^{22}$ Although its terms apply to men and women alike and forbid any denial of voting rights on account of sex, it does not prevent a state from exempting women from paying poll taxes. ${ }^{23}$

\section{II}

\section{Federal Legislative Limitations}

The only specific grant to Congress of power over the appointment and functioning of presidential electors is paragraph four, section one, of article two of the Constitution authorizing it to "determine the time of choosing the electors and the day on which they shall give their votes, which day shall be the same throughout the United States." Obviously, no state can vary the dates set by Congress for these functions. Thus, a Montana wartime statute which delayed the counting of servicemen's ballots was an unconstitutional attempt to extend the time for appointing electors beyond the date established by Congress. ${ }^{24}$ In $M c P h e r s o n$ v. Blacker, ${ }^{25}$

17 "The right of citizens of the United States to vote shall not be denied or abridged by the United States or by any State on account of race, color, or previous condition of servitude."

${ }_{18}$ United States v. Reese, 92 U.S. 214 ( 1875 ).

10 Lane v. Wilson, 307 U.S. 268 (1939); Guinn v. United States, 238 U.S. 347 (1915).

${ }^{20}$ Davis v. Schnell, 81 F. Supp. 872 (S.D. Ala. 1949), aff'd, 336 U.S. 933 (1949).

21 "The right of citizens of the United States to vote shall not be denied or abridged by the United States or by any State on account of sex."

"Graves v. Eubank, 205 Ala. 174, 87 So. 587 (I921); In re Cavellier, I59 Misc. 212, 287 N.Y. Supp. 739 (Sup. Ct. 1936); State v. Mittle, I20 S.C. 526, rr3 S.E. 335 (I922).

${ }_{23}$ Breedlove v. Suttles, 302 U.S. 277 (1937).

${ }^{24}$ Maddox v. Board of State Canvassers, II6 Mont. 217, 149 P.2d 112 (1944). This principle, would have invalidated a resolution introduced in the Louisiana legislature in 1960 seeking to suspend the state's election laws and appoint independent electors after Kennedy electors had won. Hearings Before the Senate Judiciary Subcommittee on Constitutional Amendments on Nomination and Election of President and Vice President and Qualifications for Voting, 87th Cong., Ist Sess. 402, 455 (1961).

${ }^{85}{ }_{146}$ U.S. I (1892). 
the Michigan statute set a date for the electors to meet and cast their votes which was, different from that prescribed by Congress. This provision was held unconstitutional and severed from the law, thus leaving the electors bound to meet on the day fixed by Congress.

Do these express grants exhaust the power of Congress over the appointment of electors? The question has been clouded somewhat by the concept of electors as "state officers" resulting from the broad language of Mr. Justice Gray in In re Green. ${ }^{20}$ A lower federal court had granted habeas corpus for a prisoner convicted under state law of fraudulent voting for members of Congress and presidential electors on the grounds that Congress had legislated on election offenses in congressional elections and it was exclusively a federal matter. The Supreme Court reversed, holding that the state could prescribe election offenses in voting for presidential electors regardless of whether it had concurrent power with Congress over congressional elections. Of presidential electors, the Court said, "they are no more officers or agents of the United States than are members of the state legislatures when acting as electors of Representatives in Congress."27 Mr. Justice Gray went beyond the requirements of the case, but he said only that electors are not "federal officers." $\mathrm{He}$ did not say that electors necessarily are "state officers." Although accepting that electors are not federal officers, state courts have divided on whether they are to be treated as state officers. For various purposes under state law, courts of Oklahoma, ${ }^{28}$ Kentucky, ${ }^{29} \mathrm{Ohio}^{30}$ and South Carolina ${ }^{31}$ have applied the "state officer" label. Texas held that presidential electors were not "state officers" under its statutes requiring such to be nominated by primary elections, limiting the term to offices existing by virtue of the laws of Texas. ${ }^{32}$ The Supreme Court of Idaho followed similar reasoning to hold that electors were not state officers within a statute permitting nomination by petition. ${ }^{33}$ The Supreme Court of California in Spreckels v. Graham ${ }^{34}$ held that the position is not a "public office" within the meaning of a similar statute. The court considered the possibility that electors may not be officers at all in the usual sense of the word since they have no tenure of office and do not exercise any sovereign functions of government. This view has respectable support $^{35}$ and suggests that the elector's function is the touchstone for determining the scope of federal power over him.

The elector's unique role precludes any attempt to assimilate his status to that of other functionaries, state or federal. His peculiar constitutional function is a matter of both state and federal concern and it is unnecessary to draw rigid lines between

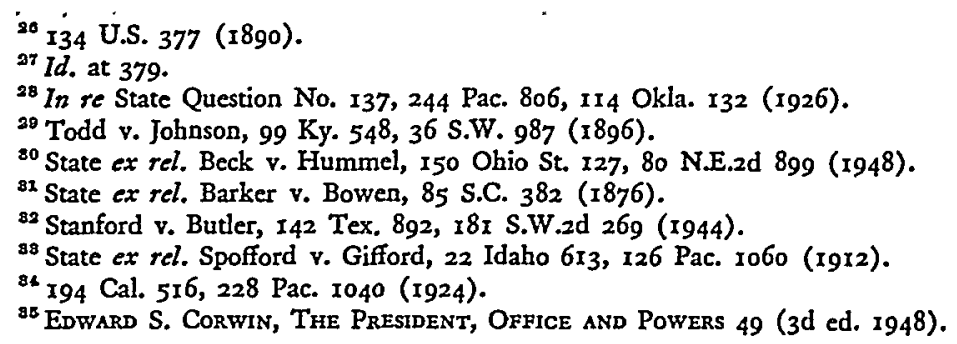


them. For instance, Congress has, without question, ${ }^{36}$ legislated in detail concerning the manner of certifying electors' appointments, the transmission of their credentials and votes, filling vacancies, resolving election contests, and so on. ${ }^{37}$ This legislation can probably be upheld as necessary and proper to Congress' constitutional duty to count the electoral votes. Any interference with the state's power over appointment of electors is only incidental to the establishment of an orderly counting procedure. But this is not the extent of Congress' implied powers over the initial appointment. In Ex parte Yarbrough, ${ }^{38}$ the Court sustained a congressional enactment punishing conspiracy to prevent citizens from lending aid towards the election of presidential electors. Although both congressional and presidential elections were involved, the Court's opinion made no distinction between the two and upheld the exercise of federal power both under the fifteenth amendment and as a necessary attribute of political sovereignty to protect the election of federal officers from the influence of violence, corruption, and fraud.

In Burroughs v. United States, ${ }^{39}$ the Court extended the Yarbrough principle to hold that the Federal Corrupt Practices Act, regulating political contributions, applied to elections of presidential electors. While adhering to the view. that electors are not federal officers, the Court emphasized their exercise of federal functions under the Constitution and upheld the statute under an inherent sovereign "power of self-protection," which necessitates power in Congress to protect the election of national officers from fraud and corruption. In recent years, the doctrine of Yarbrough and Burroughs has been cited to justify proposed federal anti-poll tax legislation ${ }^{40}$ and regulation of literacy tests. ${ }^{41}$

The extension of federal power to congressional primary elections ${ }^{42}$ has also been cited as supporting congressional authority to legislate for national presidential primary elections. ${ }^{43}$ However, so long as the appointment of electors continues to be a constitutional prerogative of the states, and so long as electors are constitutionally free to vote for anyone in the electoral college, it is difficult to see how simple legislation for presidential primaries could confine the elector's choice to those nominated by the primaries. ${ }^{44}$

The fourteenth, fifteenth, and nineteenth amendments each authorize Congress to enforce their provisions by appropriate legislation. Valid congressional enactments pursuant to any of these articles would contravene inconsistent state laws by

\footnotetext{
${ }^{B 0}$ One annotator says that it is by "general agreement" that Congress has regulated electors' performance of their duties. Annot., 153 A.L.R. 1066 (1944).

${ }_{37}$ U.S.C. $\S \S \mathrm{I}-\mathrm{r} 8$ (I958). ${ }^{38}$ I I0 U.S. $65 \mathrm{~T}$ (I884). ${ }^{30} 290$ U.S. 534 (I934).

10 Kallenbach, Constitutional Aspects of Federal Anti-Poll Tax Legislation, 45 Mrck. L. Rev. 717, 724 (1947); Christensen, The Constitutionality of National Anti-Poll Tax Bills, 33 MrNN. L. REv. 217, 25 I (I949).

"See the brief of the Attorney General of the United States, in Hearings Before the Senate Tudiciary Subcommittee on Constitutional Rights on S. 480, S. 2750, and S. 2979, 87th Cong., 2d Sess. 302, $31 \mathrm{I}$ (1962).

12 Upheld in United States v. Classic, 313 U.S. 299 (1941).

13 Hearings Before a Subcommittee of the Senate Committee on Rules and Administration on S. 257o, $82 d$ Cong., $2 d$ Sess. 40-43 (1952).

"CoRwin, op. cit. supra note 35 , at 4 I.
} 
virtue of the federal supremacy clause, but no congressional exercise of these powers has yet directly conflicted with state.regulation of appointment of presidential electors. The proceedings in the Eighty-seventh Congress on the Kennedy Administration's literacy test bill disclosed wide differences of opinion as to how far Congress can go under the fifteenth amendment in regulating state administration of literacy qualifications for voting. 45

World War II legislation to enable servicemen to vote by absentee ballot focused attention on the war power as a basis of congressional regulation of presidential elections. The Act of September 16, $1942^{46}$ gave members of the armed forces the right to vote for members of Congress and presidential electors notwithstanding provisions of state law requiring registration and payment of poll taxes. States having poll taxes then modified their laws to comply with the statute and its constitutionality was never tested. ${ }^{47}$ By the Act of April I, I944, ${ }^{48}$ these provisions were abandoned and a War Ballot Commission was established to distribute official war ballots, but the validity of the ballots was left to be determined by state election officials under state laws. In view of the virtually unlimited scope of the war power and the cases holding that the Soldiers and Sailors Civil Relief Act overrode otherwise valid state laws, ${ }^{49}$ there is little doubt that such congressional legislation would supersede state presidential election laws.

\section{III}

\section{State Constitutional Limitations}

McPherson $v$. Blacker suggested that the power of state legislatures over presidential elections is plenary and cannot be limited by state constitutions. ${ }^{50}$ Although there is surprisingly little case law on the point, the question is both important and timely.

Millions of mobile American voters are disfranchised by outmoded residence qualifications. Upon moving to a new state, they do not meet its residence requirements, but they cannot vote by absentee ballot at their previous home because they are no longer legal residents there. The trend is to relieve these persons by special provisions for presidential elections. Most states' residence qualifications are prescribed by their constitutions. ${ }^{51}$ Can state legislatures deal with the problem by

${ }^{45}$ See the divergent opinions of constitutional law professors in Hearings, supra note $4 \mathrm{I}$, at 573-664.

${ }^{13}$ Ch. $56 \mathrm{x}, \S 2,56$ Stat. 753.

${ }^{47}$ Kallenbach, supra note 40, at $7 x 9$.

${ }^{48} \mathrm{Ch} .150,58$ Stat. 136.

${ }^{10}$ E.g., Hoffman v. Charlestown Five Cents Saving Bank, 231 Mass. 324, I21 N.E. 15 (1918); Pierrard v. Hoch, 97 Ore. 7x, Igr Pac. 328 (1920).

${ }^{50}$ At ${ }^{4} 6$ U.S. 34 , the Court quoted with approval the following statement made in 1874 by a Senate Committee:

"The appointment of these electors is thus placed absolutely and wholly with the legislatures of the several States. . . . This power is conferred upon the legislatures of the States by the Constitution of the United States, and cannot be taken from them or modified by their State constitutions any more than can their power to elect Senators of the United States. Whatever provisions may be made by statute, or by the State constitution, to choose electors by the people, there is no doubt of the right of the legislature to resume the power at any time, for it can neither be taken away nor abdicated."

${ }^{s 1}$ Hearings, supra note 24 , at $48 \mathrm{r}-89,844-57$. 
legislation or must the generally cumbersome procedure of constitutional amendment be utilized?

New Jersey's experience in Ig60 is a case in point. The Assembly passed a bill which would have allowed an otherwise qualified voter who moved out of New Jersey to vote in its presidential elections by absentee ballot if he had not resided at his new home for a sufficient period to qualify there. The governor vetoed the bill on grounds of unconstitutionality, relying on provisions of the New Jersey Constitution limiting voting in all elections to persons residing in the state at the time. The governor acknowledged the contrary dictum of McPherson v. Blacker ${ }^{52}$ but concluded that "in the absence of a definitive decision ... . we should not lightly assume that the legislature can override our Constitution in this respect."

The question is important and is likely to recur. If we take literally the mandate of the United States Constitution that a state's presidential electors shall be appointed in such manner as its legislature shall direct, then the legislature can disregard state constitutional provisions on voting qualifications. Furthermore, if this is a plenary power granted directly by the United States Constitution to the legislature as a body, then the New Jersey Assembly could also act independently of the governor. The answers are not clear-cut, but it appears that in the first instance the legislature is free of state constitutional limitations but in the second is subject to it.

The question is posed: By the term "legislature" did the framers of the United States Constitution intend to vest this power solely in the representative assembly which made the state's laws, or did they intend merely to refer the problem to the state's legislative procedures as defined and limited by each state's constitution? The intent of the framers would be controlling if ascertainable but a reading of the debates in the Constitutional Convention and State Ratifying Conventions is of little assistance. The framers were never concerned with limitations which might be imposed by the states upon their legislatures' power or with possible distributions of state legislative power beyond the representative assembly. Only two states had executive vetoes, and referendum and initiative were nonexistent. When the electoral college scheme was finally accepted, it was a "jerry rigged improvisation" "54 whose principal virtue was that it was a political compromise which passed the buck to the states and to future generations to work out elections of the President.

The process by which the Convention laboriously reached its final product indicates that the framers were seeking an electorate for the President. ${ }^{55}$ National popular election was rejected early, principally because of suffrage problems. The national legislature, state executives and the state legislatures were all considered and rejected. When it was accepted that electors would be chosen as directed by state

"Supra note 50.

${ }^{53}$ Message of Governor Robert B. Meyner to the General Assembly of New Jersey, accompanying Assembly Bill No. 684, December 19, 1960.

th This proposition is developed brilliantly in Roche, The Founding Fathers: A Reform Caucus in Action, 55 AM. Pol. Scr. Rev. 799, 8ro (I96r).

${ }^{6 \tau}$ For a good summary of the development of the electoral college provisions, see Martin, Presidential Electors, Let the State Legislatures Choose Them, 44 A.B.A.J. II82 (1958). 
legislatures, most realized that the legislature itself could appoint the electors if it chose. Madison predicted that in most cases, the legislatures themselves would determine the appointment of the President. ${ }^{5 B}$ Considering the path by which the term "legislature" got into this clause, it is a safe guess that most delegates to the Convention were thinking of their state legislative assembly as a body when they approved the final draft. But this does not mean that the framers affirmatively intended that the legislatures should act in violation of state organic law which created and vested in them the legislative power. The point simply did not occur to them.

The term "legislature" was used thirteen times in the original Constitution, exclusive of amendments. In the great majority of instances it obviously refers to the states' representative lawmaking assemblies. ${ }^{57}$ Only two of these references have received authoritative judicial construction. In one clause, "legislature" was held to mean the state's representative assembly as a body and in the other it was construed to refer to the states' lawmaking procedure.

The meaning of the term in article five, concerning ratification of constitutional amendments by the several state legislatures, was settled by Hawke $v$. Smith. ${ }^{\text {88 }}$ A provision of the Ohio Constitution required that ratification of proposed amendments be submitted to referendum. The Supreme Court held that the Ohio legislature's ratification of the prohibition amendment was effective without approval by referendum. The term "legislature" meant "the representative body which made the laws of the people." Ratification was viewed not as legislative, but as "the expression of the assent of the state." The holding did no violence to state legislative procedures. No law in the usual sense of the word results from a single legislature's ratification of a proposed amendment. Its action is a nullity unless a sufficient number of other states concur. The holding was consistent with the early ruling that action of Congress in proposing an amendment is nonlegislative in character and need not be approved by the President. ${ }^{00}$

This same functional approach to duties of state legislatures produced an opposite result in Smiley $v$. Holm, ${ }^{61}$ when the Court considered article one, section four, which authorizes state legislatures to prescribe the time, places, and manner of electing representatives to Congress. Here the term was held to refer to the lawmaking power of the state. Congressional districting legislation was therefore subject to veto by the governor. Unlike electing Senators and expressing the state's assent

${ }^{50}$ The Federacist No. 45 (Madison) (Hamilton ed. 1866).

${ }^{87}$ In the following clauses of the Constitution the term obviously means the lawmaking bodics: art. I, \$ 2, providing for election of Representatives by "electors of the most numerous branch of the state legislature"; art. I, \$3, concerning election of Senators by legislatures; art. I, \$ 8, para. 17, providing for legislature's consent to Federal purchase of land within a state; art. IV, $\$ 3$, concerning legislatures' consent to junction of states; art. IV, $\$ 4$, providing for protection from domestic violence by the United States upon application of the legislature; art. VI, oath of members of state legislatures.

${ }^{88} 253$ U.S. 221 (1920). Accord, Leser v. Garnett, 258 U.S. 130 (1922); National Prohibition Cases, 253 U.S. 330 (1920).

${ }^{50} 253$ U.S. at 229.

${ }^{00}$ Hollingsworth v. Virginia, 3 U.S. (3 Dall.) 378 (1798).

1285 U.S. 355 (1932). 
to some act of the national government, regulations of congressional elections have the force of law and exercise legislative power. As the highest New York court had noted in reaching the same result, this involves "a direction to the people of the State demanding certain things to be done . . . a mandate, the disobedience of which would result in penalties or legal consequences." ${ }^{, 22}$ In Carroll $v$. Becker, ${ }^{63}$. the Supreme Court of Missouri held in accord by reasoning from a presumption that when the legislature is assigned a certain duty, it must be performed by the enactment of a law, unless the context implies the exercise of some other function. The Missouri court distinguished ratification of amendments, like election of Senators, as a ministerial act commanded by the Constitution where no law is enacted.

A functional analysis-looking to the nature of the action-dictates that legislatures' direction of the manner of appointing electors should be treated the same as their prescription of the manner of electing congressmen. Both are legislative in nature.

An interesting Senate precedent is analogous. When senators were still chosen by state legislatures, a joint resolution of the New Jersey legislature made a plurality of the entire legislature sufficient for election. The Senate refused to seat a candidate who was elected in this manner. Although Senators could be elected by joint convention, the prescription of a plurality rule was legislative in nature and could be authorized only by a measure enacted in the manner required for legislation and having the force of law. ${ }^{64}$

The few cases on presidential elections which have considered the question are consistent with this view. The Supreme Court of Maine held in IgIg that referendum provisions of its state constitution applied to legislation granting women the right to vote for presidential electors. "The term "legislature" in the United States Constitution was construed to mean "simply that a state shall give expression, as it must of necessity, through its lawmaking body, the legislature . . . in accordance with and in subjection to the Constitution of the State, like all other acts and resolves having the force of law."

In the Maine case, as well as in Smiley v. Holm, the issue was how the legislative power of the state was exercised. If the state's organic law includes popular referendum or executive veto in its legislative process, the procedure applies to laws governing presidential elections. This does not end our inquiry. There is a difference between how and what. State constitutional provisions such as veto, initiative, and referendum are a distribution of the legislative power of the state. It is to this legislative power, as defined by the state organic law, that the United States Constitution refers the appointing of presidential electors. Once legislative power is exercised in the manner fixed by the state constitution, it does not necessarily follow that the scope or substance of the enactment is restricted by state constitutional

\footnotetext{
${ }^{62}$ Koenig v. Flynn, 258 N.Y. 292, 300, I79 N.E. 705, 707 (1932) affd, 285 U.S. 375 (I932).

${ }^{63} 329$ Mo. 50r, 45 S.W.2d 533 (1932), affd, 285 U.S. 380 (r932).

oc George S. Taft, Senate Election Cases 322 (rgo3) (decided in I866).

os In re Opinion of the Justices, 118 Me. 552, 107 Atl. 705 (1919).

${ }^{\circ 0}$ Id. at 554, 107 Atl. at 706.
} 
provisions, as was feared by the governor of New Jersey. The precedents indicate that such state legislation is not limited by constitutional provisions on voting qualifications or election procedures.

During the War Between the States, ${ }^{67}$ and again in World War $I_{,}{ }^{08}$ New Hampshire held that a constitutional provision requiring voting in person did not invalidate legislation allowing soldiers to vote for presidential electors by absentee ballot. Vermont upheld similar legislation during the War Between the States despite the same constitutional limitation. ${ }^{69}$

State ex rel. Beeson v. Marsh ${ }^{70}$ held that Nebraska could constitutionally limit candidates for presidential elector to those nominated by political party conventions. The court found it unnecessary to consider whether this statutory procedure violated a state constitutional provision for free elections on the grounds that such a provision "may not operate to circumscribe the legislative power granted by the Constitution of the United States." the same reasoning to reach a similar result. ${ }^{72}$

An especially well-reasoned decision is Commonwealth ex rel. Dummit $v$. $O^{\prime}$ Connell, ${ }^{73}$ a World War II Kentucky decision. It draws the distinction which this author regards as controlling. Although the Kentucky Constitution required voting in person, the court upheld legislation allowing servicemen to vote by absentee ballot in elections of members of Congress and presidential electors. For both types of elections, the court considered that the United States Constitution granted a legislative power unaffected by substantive state constitutional restrictions. Smiley v. Holm was distinguished as meaning only that a legislature must function "in the method prescribed by the State Constitution," but that when the legislature functions in the prescribed manner, "the scope of its enactment" is not also limited. ${ }^{74}$

In summary, it is safe to assume that state legislatures are limited by constitutional provisions for veto, referendum, and initiative in prescribing the manner of choosing presidential electors, but that state constitutional provisions concerning suffrage qualifications and the manner of choosing electors do not limit the substantive terms of legislation. Acceptance of this distinction by the courts would facilitate adoption of a uniform state law on residence qualifications recently proposed by the Conference of Commissioners on Uniform State Laws ${ }^{75}$ and recommended by the American Bar Association. ${ }^{76}$

- ${ }^{\circ 7}$ Opinion of the Justices, 45 N.H. 595 (1864).

${ }^{68}$ Opinion of the Justices, 80 N.H. 595, Ir3 Atl. 293 (I92I).

${ }^{08}$ Opinion of the Justices, 37 Vt. 665 (1865).

- $\quad 71$ Id. at 246,34 N.W.2d 287 .

79 Parsons v. Ryan, I44 Kan. 370, 60 P.2d 910 (1936).

${ }^{73} 298 \mathrm{Ky} .44$, I81 S.W.2d 691 (I944).

75 A press release issued by the Conference on August 4,1962 , announced approval of a uniform act which would allow otherwise qualified new residents of a state to vote "by filing an application in ample time to enable election officials to process the application and take safeguards against fraudulent and double voting." I38 CoNG. Rec. A6604 (daily ed. Aug. 8, 1962) (reprinted with remarks of Senator Kefauver).

${ }^{70}$ N.Y. Times, Aug. I1, 1962, p. I8, col. 1. 


\section{Elector Discretion}

How far can the legislature go in controlling the individual elector's vote in the electoral college? Does its power over appointment enable it to require that an elector forfeit his discretion and bind his vote in order to be appointed?

Again, there is little case law and much doubt, but the defecting Republican elector in Oklahoma in I 960 has focused new attention on the nature of the elector himself. This elector believed that he was not only exercising a constitutional right but performing his constitutional duty by casting an independent vote. ${ }^{77}$ Because of this incident, it is well to begin this inquiry from a proper historical perspective of the Founding Fathers' intentions.

Although there is respectable academic authority for the view that the Framers intended electors to exercise an independent judgment, ${ }^{78}$ the preponderance of the evidence and the better-documented studies show that most of them intended the exact opposite. As Dr. Lucius Wilmerding concluded, "the Framers wanted and expected the popular principle to operate in the election of the President."79

Those who differ with Wilmerding rely heavily on Alexander Hamilton's statement in the Federalist No. 68 that the election of the Chief Magistrate would be determined by the deliberation of "a small number of persons . . . most likely to possess the information and discernment requisite to such complicated investigation." $"$ Although Hamilton's role in the Convention perhaps entitles his interpretation to more weight than that of any other man, his view doubtless was colored by his personal hopes. Other distinguished members of the Convention expected the electors to reflect the will of the people of the state which appointed them and used this as a selling point in the ratifying conventions. General Charles Coatesworth Pinckney told the South Carolina convention that the President was "to be elected by the people, through the medium of electors chosen particularly for that purpose." 81 In Pennsylvania, James Wilson apologetically told the Convention that "the choice of this officer is brought as nearly home to the people as is practicable. With the approbation of the state legislatures, the people may elect with only one remove." 82 Governor Randolph of Virginia, although having many doubts about the Constitution, stated without reserve: "How is the President elected? By the people-on the same day throughout the United States-by those whom the people please." One of the caustic George Mason's criticisms in the Virginia debates was that the electoral college proposal was "a mere deception-a mere ignis fatuus

\footnotetext{
${ }_{77}$ Testimony of Henry D. Irwin, in Hearings Before the Senate Judiciary Subcommittee on Constitutional Amendments on Nomination and Election of President and Vice President and Qualifications for Voting, 87th Cong., rst Sess. 562 (xg6r).

${ }^{78}$ James Bryce, The American Commonweal.th 4 I-43 (3d ed. I899); Corwin, op. cit. supra note 35, at $49-52$.

${ }^{70}$ Lucius Wilmerding, The Electoral College 21 (1958).

80 The Federalist No. 68, at 509 (Hamilton) (Hamilton ed. I866).

.. 814 Jonathan Elliot, Debates on the Federal Constitution 304 (2d ed. 1836).

${ }^{82} 2$ id. at $5 \mathrm{rx}$. ${ }^{83} 3$ id. at 201 .
} 
on the American people,-and thrown out to make them believe they were to choose him." 84

As one observer has noted, the Framers did not intend the electors to be a "College of Cardinals" and it is "historical phantasy" for an elector to assume that they intended him to exercise an independent judgment. ${ }^{85}$ The electors were but an essential ingredient of a masterpiece in deliberately vague political compromise which enabled the Framers to agree on their most difficult issue and yet allowed those of each viewpoint to return home and claim they had carried the day. ${ }^{80}$

Nonetheless, the view is widely held that the Framers left electors free of any effective legal control of their discretion. ${ }^{87}$ State legislative power was limited to their appointment. Then they are directed by the Constitution to meet and "vote by ballot," a mandate which seems to imply both a free and a secret vote.

The early gearing of state election laws to the two-party system has been almost universally successful in producing electors who were faithful to popular will and party candidates without direct legal compulsion. To this end, the courts generally has given wide latitude to party organizations and frequently have given strained construction to statutes in order to aid party regularity and encourage orderly elections.

A state may require that all candidates for elector be nominated by primary election ${ }^{88}$ or by convention of an organized political party, ${ }^{80}$ or require established parties to nominate by primary while permitting new parties to nominate by convention. ${ }^{90}$ General statutes for nomination of candidates for office by petition usually have been interpreted to exclude electors. ${ }^{91}$ Ohio law was held to allow nomination of independent candidates for elector by petition but the court held that, unlike party nominees, they were not entitled to have the ballot show the name of the presidential candidate to whom they were pledged.92

The most significant recent development in the nominating process is the trend away from primaries to nomination by party conventions or committees. In 1948, only seven states still required nomination by primary ${ }^{93}$ and now only Arizona ${ }^{04}$ remains in this category. In thirty-seven states parties now nominate by con-

st Id. at 493 .

${ }^{80} \mathrm{Tbid}$.

${ }^{87}$ E.g., CoRwiN, op. cit. supra note 35 , at 41 ; Silva, State Law on the Nomination, Election and Instruction of Presidential Electors, 42 AM. PoL. Scr. Rev. 523, 529 (1948). See also dissenting opinion of Mr. Justice Jackson in Ray v. Blair, 343 U.S. 2I4, 232 (1952).

${ }^{88}$ Wiggins v. Ryan, 152 Kan. 629, I06 P.2d 71x (1940); Lillard v. Cordell, 200 Okla. 577, 198 P.2d 417 (1948).

${ }^{80}$ State ex rel. Beeson v. Marsh, 150 Neb. 233, 34 N.W.2d 279 (1948); Markham v. Bennion, 122 Utah 562, 252 P.2d 539 (1953).

${ }^{00}$ Mills v. Stewart, 64 Mont. 453,2 ro Pac. 465 (Ig22).

${ }^{21}$ Spreckles v. Graham, 194 Cal. 516, 228 Pac. 1040 (1924); State ex rel. Spofford v. Gifford, 22 Idaho 6r3, 126 Pac. 1060 (1912).

${ }^{92}$ State ex rel. Beck v. Hummel, 150 Ohio St. I27, 80 N.E.2d 899 (1948).

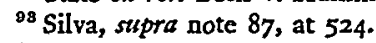

of ARIz. REv. STAT. \$\$ 16-30I, 16-305, 16-502, 16-503 (1956). A 1961 survey listed both Arizona and Kansas in this category. Hearings, supra note 77, at 718 , but the Kansas law was amended in 1961 to require nomination by convention. S.B. No. 330, ch. $200, \$ 3$. 
vention ${ }^{95}$ and in eight states ${ }^{96}$ it is handled by the party state committee. Four states have special provisions. ${ }^{97}$

On occasion, miscarriages in the nominating process have brought party officials into court in attempts to insure elector fidelity. The courts have generally been sympathetic and, at times, ingenious in granting relief. A notable example is State ex rel. Nebraska Republican Central Committee v. Wait, ${ }^{98}$ where a group of electors who had been nominated by the Republican Party subsequently also accepted nomination as Progressive Party electors but refused to withdraw from the Republican slate. The court held that acceptance of the Republican nomination for elector implied a pledge to vote for its candidates if elected and that upon becoming a Progressive nominee each accepted an incompatible office which worked a forfeiture of his office as Republican elector. This created vacancies in the Republican slate which could be filled under state law by the Republican State Committee.

In Louisian ${ }^{99}$ and Texas, ${ }^{100}$ where electors were nominated by party organizations, cases arose where nominees then announced refusals to vote for the party candidates if elected. In both instances, it was held that the party could rescind their nomination and substitute new nominees.

The Alabama courts faced a somewhat different situation in 1948 when a candidate for elector in the regular Democratic primary announced that he would not vote for Truman if he ran on a civil rights platform. An injunction was sought to restrain the elector from voting for Thurmond, but it was denied on jurisdictional grounds. ${ }^{101}$

Improvements in the makeup of the general election ballot have also operated to insure elector fidelity and to enable voters to express their choice directly for the presidential candidates. The "short ballot," now used by thirty-two states, ${ }^{102}$

ot Alaska, California, Colorado, Connecticut, Hawaii, Illinois, Indiana, Iowa, Kansas, Kentucky, Louisiana, Maine, Maryland, Michigan, Minnesota, Mississippi, Missouri, Montana, Nebraska, Nevada, New Hampshire, New Jersey, New Mexico, North Carolina, North Dakota, Ohio, Oklahoma, Rhode Island, South Dakota, Texas, Utah, Vermont, Virginia, Washington, West Virginia, Wisconsin, and Wyoming. This list is extracted from Nomination and Election of the President and Vice President of the UNIred STATEs (printed for the use of the Secretary of the Senate, 1960), with the addition of Kansas. See note 94 supra.

${ }^{\circ 0}$ Arkansas, Georgia, Idaho, Massachusetts, New York, Oregon, South Carolina, and Tennessee. Hearings, supra note 77 , at 718 .

${ }^{\circ 7}$ In Alabama, nomination is by the method chosen by the party organization. ArA. Code tit. $17, \$ \S 65,66,145$ (1940) (Supp. 1955, 1957). In Delaware the party organization chooses between the convention and committee methods. DEL. CoDE tit. 15, ch. 33 (1953). The governor of Florida nominates electors on recommendation of the party's state committee. Fla. STAT. ANN. $\$ 103.021$ (Supp. r959). The presidential candidate of each party nominates Pennsylvania's electors. 25 PA. STAT. ANN. $\$ \$ 2878,2913$ (Purdon 1938, Supp. 1958).

${ }^{\circ 8} 92 \mathrm{Neb} .313,138$ N.W. 159 (1912).

90 Browne v. Martin, I9 So.2d 421 (La. 1944).

${ }^{100}$ Seay v. Latham, I43 Tex. I, I82 S.W.2d 251 (1944).

${ }^{101}$ State v. Albritton, 25 I Ala. 422, 37 So.2d 640 (1948).

${ }^{102}$ Alaska, California, Colorado, Connecticut, Delaware, Florida, Hawaii, Illinois, Indiana, Iowa, Kentucky, Maine, Maryland, Massachusetts, Michigan, Minnesota, Missouri, Nebraska, Nevada, New Hampshire, New Jersey, New Mexico, North Carolina, Ohio, Oregon, Pennsylvania, Rhode Island, Texas, Utah, Washington, West Virginia, and Wisconsin. Statutes are collected by Wilkerson in The Electoral Process and the Power of the States, 47 A.B.A.J. 25I, 253 (I96I). 
does not show the electors' names, only the candidates for President and Vice President. The elector's pledge to vote for these candidates is implied. Fifteen states ${ }^{103}$ list both electors and candidates for President and Vice President, implying to both voter and elector that the electors and nominees are a unit. Only four states authorize what might be called "unpledged electors" in the true sense by allowing electors to be listed under the party label without showing the names of any candidates for President and Vice President. ${ }^{104}$

Nine states go beyond the implied pledge with statutes directing electors to vote for the party nominees. ${ }^{105}$ Only three states actually require some form of personal pledge or oath by the elector expressly stating that he will vote for the party nominee. ${ }^{108}$ No state law purports to provide any means of actually converting an elector's appointment into an electoral vote for a particular candidate.

The state court decisions concerning independence of electors have taken some interesting turns. In South Dakota a state law limiting nominating petitions to one office for each petition was held to permit all presidential electors to be treated as one office for nomination purposes because "presumably this group stands as a unit for one candidate for President."107

In holding that Ohio could constitutionally limit the presidential candidates' names on its ballot to those nominated by national conventions (and thus requiring that Wallace's 1948 electors run solely as individuals), the Ohio court pointed out that all electors, regardless of how chosen, were free to vote as they pleased, it being "only by force of a moral obligation, not a legal one, that the presidential electors pledged to certain candidacies fulfill their pledges after election."10s But when New York's short ballot was challenged by a citizen who claimed the right to know what electors he was voting for, a lower court held that their identity was immaterial because by force of custom electors had come to have a legal duty which could be enforced by mandamus compelling them to vote for party nominees. ${ }^{100}$ In 1896 , Thomas E. Watson sought to withdraw his name from the Kansas ballot where he was listed with electors of the Peoples' Party as their candidate for Vice President as a running mate with Bryan. He alleged that the electors did not intend to vote

${ }^{103}$ Arizona, Idaho, Kansas, Louisiana, Mississippi, Montana, New York, North Dakota, Oklahoma, South Carolina, Tennessee, South Dakota, Vermont, Virginia, and Wyoming. Wilkerson, stlpra note I02.

104 ALA. CODE tit. I7, $\$$ I45 (I940) (Supp. I955, I957); ARK. STAT. $\$ \$ 3-325,3-328$ (Supp. 1959); GA. Code ANN. $\$ 34-2513$ (Supp. 1959) (temporary legislation expiring in 1962); Miss. Code ANN. \$ 3107.5 (1942: 1956 Recomp. Vol.) (permits party to enter slate of unpledged electors in addition to pledged slate).

${ }_{105}$ Alaska, California, Colorado, Florida, Hawaii, Idaho, Michigan, New Mexico, and New York. Hearings, supra note 77 , at 719 .

${ }^{100}$ Fla. Stat. ANN. $\$ 103.21$ (Supp. I960); 26 OkLA. Stat. AnN. $\$ \$$ 519-22 (I9G2); Ore, RBV. STAT. \$248.355.

${ }^{107}$ Johnson v. Coyne, 47 S.D. 138, I42, I96 N.W. 492, 493 (1923).

${ }^{208}$ State ex rel Beck v. Hummel, $x 50$ Ohio St. 127, 146, 80 N.E.2d 899, 909 (1948).

${ }^{100}$ Thomas v. Cohen, 146 Misc. $836,841-42,262$ N.Y. Supp. 320, 326 (I933). So liberal a view was hardly necessary to the decision. The short ballot is a permissible exercise of the legislature's broad power over appointment. State ex rel. Beeson v. Marsh, 150 Neb. 233, 34 N.W.2d 279 (1948); State ex rel. Hawke v. Myers, 132 Ohio St. 18, 4 N.E.2d 397 (1936). 
for him but for Sewell who was Bryan's running mate on the Democratic ticket. The court held Watson could not withdraw because he was not a nominee. Voters did not vote for him but instead for electors who were under "no legal obligation" to support anyone and "authorized to use their own judgment as to the proper eligible persons to fill these high offices."110

In Ray v. Blair, ${ }^{111}$ the United States Supreme Court held that it was not unconstitutional for the Alabama Democratic Party to require a pledge as a condition of running in its primary for nomination for presidential elector. The Court left unanswered a contention that the pledge would not be enforceable if an elector chose to violate it. If an elector chooses to incur party and community wrath by violating his trust and voting for some one other than his party's candidate, it is doubtful if there is any practical remedy. Once he is appointed, he is to vote. Legal proceedings which extended beyond the date when the electors must meet and vote would be of no avail. If mandamus were issued and he disobeyed the order, no one could change his vote or cast it differently. If he were enjoined from voting for anyone else, he could still abstain and deprive the candidate of his electoral vote.

Oklahoma's solution after its Ig60 experience was a law requiring a sworn oath of a nominee for elector that he would vote for his party's candidate and imposing up to $\$ \mathrm{r}, 000$ fine if he votes otherwise. ${ }^{112}$ This seems to concede his legal power to vote as he chooses if he is willing to incur the fine. Although constitutionality of the penalty is not free from doubt, the legislative power over appointment would probably sustain its imposition against one who took and violated such an oath.

A law which would fully test legislative power over elector discretion would be one which automatically forfeited his office upon casting a defecting vote. Other electors or party officials could be authorized to fill the vacancy on the spot. His initial appointment would have been conditional upon his performing his promise. This would require open voting and would certainly encounter a contention that the balloting must be secret. ${ }^{113}$

The best solution would be a federal constitutional amendment abolishing the office of elector and automatically awarding each state's entire electoral vote to the winner of a plurality of its popular vote. For, as a Senate Committee noted in 1826 , electors "have degenerated into mere agents in a case which requires no agency, and where the agent is useless if he is faithful, and dangerous if he is not."114

\footnotetext{
${ }^{220}$ Brcidenthal v. Edwards, 57 Kan. 332, 339, 46 Pac. 469, 471 (1896).

211343 U.S. $2 \mathrm{r}_{4}$ (I952). $\quad{ }^{112} 26$ OKLA. STAT. ANN. $\$ \$ 5$ I9-522 (I962).

${ }^{118}$ Sec Dixon, Electoral College Procedure, 3 Western Por. Q. 214, 220 (r950).

114 S. REP. No. 22, 19th Cong., Ist Sess. 4 (1826).
} 